\title{
Carryover Effect of Biochar and Cow Dung Manure on the Productivity of Green Gram (Vigna radiata L.) in Typic haplustalf
}

\author{
B.R. Arunkumar ${ }^{1}$, G.N. Thippeshappa ${ }^{2}$
}

$10.18805 / L R-4755$

\begin{abstract}
Background: In cereals based legume cropping system more importance and intensification are given to first crop (cereals) as compared to succeeding crops. Hence, succeeding crops yield got reduced due to grown in low fertile soils. Productivity of green gram have declined or stagnated in recent years though we grew high yield varieties, due to grown in marginal lands with low nutrient and moisture. Biochar is organic substance that highly persists in soils with very little biological decomposition and helps to store nutrients and moisture for succeeding crop. The present investigation was felt necessary to get utilize the residual soil nutrients and moisture from the preceding biochar applied upland rice field for sustainable yield of green gram crop.

Methods: The present investigation was conducted during kharif season 2018. The study was conducted in randomized black design with sixteen treatments consisting of four levels of coconut shell biochar (CSB) at 2, 4, 6 and $8 \mathrm{t} \mathrm{ha}^{-1}$ and two levels of cow dung manure (CDM) at 5 and $10 \mathrm{tha}^{-1}$ with applied alone and in combinations with three replications (applied for previous upland rice crop). The recommended dose of NPK fertilizer (20:50:50 kg ha-1) for green gram was common except absolute control.

Result: The study results indicated that, residual effect of previously applied biochar and cow dung manure had a significant effect on succeeding green gram crop productivity in acid sandy loam soils due to its liming effect on improving soil properties and nutrient availability. Especially, combination of coconut shell biochar (CSB at $8 \mathrm{t} \mathrm{ha}^{-1}$ ) and cow dung manure (CDM at $10 \mathrm{tha}^{-1}$ ) with recommended NPK fertilizers.
\end{abstract}

Key words: Biochar, Cow dung, Green gram, Residual, Yield.

\section{INTRODUCTION}

Green gram (Vigna radiata sub sp. sublobata) is one of the important legume pulse crop in India. It is short duration crop and grown largely in marginal lands and cereal based pulse cropping system where cereals as first crop fallowed by any legume as succeeding crops. In recent year's productivity of green gram have declined or stagnated though it has developed high yield varieties, the actual yield of this legume crop is low due to grown in marginal lands with low nutrient and moisture as this crop grown as succeeding or sole in stored soil moisture and nutrients.

In cereals based legume cropping system more importance and intensification are given to first crop (cereals) as compared to succeeding crops. Hence, succeeding crops yield got reduced due to grown in low fertile soils. Maintaining soil quality plays a important role in regulation of crop yield and that is the important indicator for sustainable cropping system. The sustainability of any soils is mainly depends on its native soil organic carbon and external application of organic matter during crop production. Soil organic matter is a key indicator in improving soil physico-chemical and biological properties and helps in conservation of soil moisture and nutrients for long time. In tropical countries like India maintaining organic matter for more time in soil is big challenge as it's under rapid decomposition during hot summers. Further, soil intensive agricultural practices also increased the decomposition rate of organic matter. Hence, it is important to maintain a optimum soil organic matter for long period of time helps in yield maximization and sustainable production.
${ }^{1}$ ICAR-Krishi Vigyan Kendra, Keladi Shivappa Nayaka University of Agricultural and Horticultural Sciences, Navule, Shivamogga577 204, Karnataka, India.

${ }^{2}$ Department of Soil Science and Agricultural Chemistry, College of Agriculture, Keladi Shivappa Nayaka University of Agricultural and Horticultural Sciences, Navule, Shivamogga-577 204, Karnataka, India.

Corresponding Author: B.R. Arunkumar, ICAR-Krishi Vigyan Kendra, Keladi Shivappa Nayaka University of Agricultural and Horticultural Sciences, Navule, Shivamogga-577 204, Karnataka, India. Email: arunybr011@gamil.com

How to cite this article: Arunkumar, B.R. and Thippeshappa, G.N. (2022). Carryover Effect of Biochar and Cow Dung Manure on the Productivity of Green Gram (Vigna radiata L.) in Typic haplustalf. Legume Research. DOI: 10.18805/LR-4755.

Submitted: 30-07-2021 Accepted: 17-01-2022 Online: 11-02-2022

In this circumstances, application of biochar as an organic amendment with mineral nutrient elements improve the soil quality and yield of crops. The biochar is found to have positive impact on soil fertility, resulting in an increase in crop yield without causing hazard to soil and water environment (Warnock et al. 2007). Biochar is a finest and highly porous charcoal substance that is differentiates from other charcoals in its intended use as a soil amendment. The particular temperature treatment of organic feedstocks used to produce biochar contributes to its large specific surface area and its characteristic ability to persist in soils with very little biological decomposition (Lehmann et al., 
2006). Hence, the strategy to grow the green gram as a succeeding crop over upland rice field where coconut shell biochar and cow dung manure applied in combinations to maximize the yield. The present investigation was felt necessary to exploit the residual soil nutrients and moisture from the preceding biochar applied upland rice field for sustainable yield of green gram crop.

\section{MATERIALS AND METHODS}

The experiment was conducted at Zonal Agricultural and Horticultural Research Station, Navule, Shivamogga, belongs to Southern Transition Agro-climatic Zone of Karnataka. The research station is situated at $14^{\circ} 0^{\prime}$ to $14^{\circ} 1^{\prime}$ North latitude and $75^{\circ} 40^{\prime}$ to $75^{\circ} 42^{\prime}$ east longitude with an altitude of 650 meters above the mean sea level. The average rainfall of the zone is $873.40 \mathrm{~mm}$. Initial characterization of soil experimental site indicated that soil had a acidic $\mathrm{pH}$ of 5.88, EC of $0.22 \mathrm{dS} \mathrm{m}^{-1}$ with organic carbon content of 4.68 $\mathrm{g} \mathrm{kg}^{-1}$ and CEC of $14.43 \mathrm{cmol}(\mathrm{p}+) \mathrm{kg}^{-1}$. Further, the soil was low in available nitrogen ( $\left.213.35 \mathrm{~kg} \mathrm{ha}^{-1}\right)$, high in available phosphorus (58.17 $\mathrm{kg} \mathrm{ha}^{-1}$ ) and medium in available potassium (157.63 $\mathrm{kg} \mathrm{ha}^{-1}$ ). The soil belongs to the taxonomic class of Typic haplustalf with sandy loam texture.

Before conducting this research the experimental field was applied with different doses of biochar, cow dung and recommended dose of fertilizer for upland rice crop (grew as first crop) during summer 2017-18 with 16 treatments consisting of absolute control, recommended dose of fertilizers (NPK), four levels of coconut shell biochar (CSB) at 2, 4, 6 and $8 \mathrm{tha}^{-1}$ and two levels of cow dung manure (CDM) at 5 and $10 \mathrm{t} \mathrm{ha}^{-1}$ with applied alone and in combinations. The treatments were imposed in randomized block design with three replications. The coconut shell biochar (CSB) and cow dung manure (CDM) were applied to the soil according to treatments details 20 days and 15 days before sowing, respectively.

The second experiment was conducted during Kharif 2018 after the harvest of upland rice in the same plots of the first experiment, using legume crop (green gram). The test crop was grown to know the residual effect of different levels of CSB and CDM on growth and yield of succeeding green gram crop in the same treatment combination and layout of the earlier experiment. The only recommended dose of fertilizer NPK at 20:50:50 kg ha-1 was added to all treatments except absolute control treatment. The recommended dose of nitrogen, phosphorus and potassium were applied through urea, DAP and muriate of potash respectively during the sowing time. Observations on growth and yield parameters were recorded on randomly selected five plants from each net plot and tagged for recording the observations. The experimental data obtained were subjected to statistical analysis adopting Fisher's method of analysis of variance as out lined by Gomez and Gomez (1984). The level of significance used in the $F$ test was at 95 per cent. Critical difference (CD) values are given for the data at 95 per cent level of significance, wherever the $F$ test was significant.

\section{RESULTS AND DISCUSSION \\ Residual effect of biochar and cow dung manure on growth attributes}

Result showed a significant $(P<0.05)$ interaction on growth attributes of green gram like, plant height and number of leaves (Table 1). At 45 days after sowing and at harvest,

Table 1: Carryover effect of biochar and cow dung manure on plant growth parameters at different growth stages of green gram.

\begin{tabular}{|c|c|c|c|c|}
\hline \multirow{2}{*}{ Treatments } & \multicolumn{2}{|c|}{ Plant height $(\mathrm{cm})$} & \multicolumn{2}{|c|}{ Number of leaves plant ${ }^{-1}$} \\
\hline & 45 DAS & Harvest & 45 DAS & Harvest \\
\hline $\mathrm{T}_{1}:$ (Absolute control) & 15.18 & 19.63 & 13.57 & 12.62 \\
\hline $\mathrm{T}_{2}: 100: 50: 50 \mathrm{NPK} \mathrm{kg} \mathrm{ha}^{-1}$ (Only RDF) & 20.43 & 22.64 & 17.67 & 16.68 \\
\hline $\mathrm{T}_{3}: \mathrm{CDM} @ 5 \mathrm{tha}^{-1}$ & 21.17 & 22.85 & 18.49 & 19.06 \\
\hline $\mathrm{T}_{4}: \mathrm{CDM} @ 10 \mathrm{t} \mathrm{ha}^{-1}$ (POP) & 22.90 & 23.41 & 18.53 & 19.44 \\
\hline $\mathrm{T}_{5}: \mathrm{CSB} @ 2$ t ha-1 & 20.75 & 22.41 & 17.89 & 17.80 \\
\hline $\mathrm{T}_{6}: \mathrm{CSB} @ 4$ t ha ${ }^{-1}$ & 21.37 & 22.26 & 18.54 & 18.56 \\
\hline $\mathrm{T}_{7}:$ CSB @ 6 tha ${ }^{-1}$ & 22.16 & 23.49 & 19.10 & 19.67 \\
\hline $\mathrm{T}_{8}: \mathrm{CSB} @ 8 \mathrm{tha}^{-1}$ & 22.90 & 23.82 & 19.55 & 19.61 \\
\hline 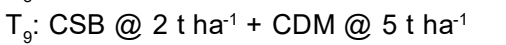 & 23.92 & 24.67 & 18.32 & 18.48 \\
\hline $\mathrm{T}_{10}: \mathrm{CSB} @ 4 \mathrm{tha} \mathrm{t}^{-1}+\mathrm{CDM} @ 5 \mathrm{t} \mathrm{ha}^{-1}$ & 24.47 & 25.69 & 18.49 & 18.60 \\
\hline $\mathrm{T}_{11}: \mathrm{CSB} @ 6 \mathrm{tha}^{-1}+\mathrm{CDM} @ 5 \mathrm{tha}^{-1}$ & 24.62 & 25.71 & 19.66 & 20.56 \\
\hline $\mathrm{T}_{12}: \mathrm{CSB} @ 8 \mathrm{t} \mathrm{ha} a^{-1}+\mathrm{CDM} @ 5 \mathrm{tha}^{-1}$ & 25.67 & 27.18 & 20.32 & 21.61 \\
\hline $\mathrm{T}_{13}: \mathrm{CSB} @ 2 \mathrm{t} \mathrm{ha}{ }^{-1}+\mathrm{CDM} @ 10 \mathrm{t} \mathrm{ha}^{-1}$ & 25.73 & 27.09 & 21.55 & 22.46 \\
\hline $\mathrm{T}_{14}: \mathrm{CSB} @ 4 \mathrm{t} \mathrm{ha}{ }^{-1}+\mathrm{CDM} @ 10 \mathrm{t} \mathrm{ha}^{-1}$ & 26.15 & 28.48 & 21.87 & 22.86 \\
\hline $\mathrm{T}_{15}: \mathrm{CSB} @ 6 \mathrm{t} \mathrm{ha}{ }^{-1}+\mathrm{CDM} @ 10 \mathrm{tha}^{-1}$ & 27.78 & 29.14 & 23.52 & 24.62 \\
\hline $\mathrm{T}_{16}: \mathrm{CSB} @ 8 \mathrm{t} \mathrm{ha}{ }^{-1}+\mathrm{CDM} @ 10 \mathrm{tha}^{-1}$ & 29.19 & 31.10 & 25.94 & 26.91 \\
\hline S.Em \pm & 1.16 & 0.95 & 1.13 & 1.26 \\
\hline C.D. $(p=0.05)$ & 3.35 & 2.74 & 3.27 & 3.63 \\
\hline
\end{tabular}

DAS -Days after sowing, *Significant at P 0.05; NS- Non significant at $\mathrm{P}>0.05$. 
significantly higher plant height was recorded in the treatment of CSB at $8 \mathrm{t} \mathrm{ha}^{-1}, \mathrm{CDM}$ at $10 \mathrm{t} \mathrm{ha}^{-1}$ with NPK fertilizers $\left(T_{16}\right)(29.19$ and $31.10 \mathrm{~cm}$, respectively) and it was on par with treatment of CSB at $6 \mathrm{t} \mathrm{ha}^{-1}, \mathrm{CDM}$ at $10 \mathrm{t} \mathrm{ha}^{-1}$ with NPK fertilizers $\left(T_{15}\right)$ which recorded 27.78 and 29.14 $\mathrm{cm}$, respectively. Similarly, significantly higher number of leaves per plant was recorded in the treatment of CSB at $8 \mathrm{t} \mathrm{ha}^{-1}, \mathrm{CDM}$ at $10 \mathrm{t} \mathrm{ha}^{-1}$ with NPK fertilizers $\left(\mathrm{T}_{16}\right)(25.94$ and $26.91 \mathrm{~cm}$, respectively) and it was on par with treatment of CSB at $6 \mathrm{t} \mathrm{ha}^{-1}, \mathrm{CDM}$ at $10 \mathrm{t} \mathrm{ha}^{-1}$ with NPK fertilizers $\left(\mathrm{T}_{15}\right)$ which recorded 23.52 and $24.62 \mathrm{~cm}$, respectively as compared to sole application of NPK fertilizers. It might be attributed to the residual effect of biochar and cow dung which provided better growing conditions to crop by continuous supply of nutrients and improvement of soil properties. Addition of biochar and cow dung manure in preceding crop and application of recommended NPK fertilizers for green gram had a positive effect on growth attributes. This could be ascribed to the slow mineralization of biochar in soil and increased the availability of nutrients to the succeeding crop as well as reduction in metal ion toxicity due to its liming effect on acid soils, as of the soil in these study were acidic in nature. Ameliorative effect of biochar will also enhance soil organic carbon and nutrients cycle which influence crop growth environment. The present study findings were in corroborated with Joseph Koireng et al. (2018) and Thakuria and Thakuria (2018).

\section{Residual effect of biochar and cow dung manure on yield and yield attributes}

Influence of residual biochar and cow dung manure on yield and yield components was significant $(P<0.05)$ depicted in
Table 2. Data on yield parameters of green gram at harvest viz., number of pod bearing auxiliary branches per plant (4.38), pod length $(8.50 \mathrm{~cm})$, number of pods per plant (25.57) and number of seeds per pod (14.36) was observed in higher dose biochar and cow dung manure applied plot (residual) and with recommended NPK. This could be attributed to the residual effect of biochar and cow dung manure provided better growing conditions to crop by continuous supply of nutrients and improvement of soil properties. The variation in crop components was considered to be due to variation in the availability of major nutrients. Increase in the effective microorganisms in the soils increases the mineralization. These results were in conformity with Rambuatsaiha and Noyingthung (2017). Mahto and Dutta (2018) observed an increase in crop yield components with previously applied low cost organic inputs as compared to fertilizer alone applied treatments. Similarly, results of Bandara et al. (2015) corroborated with present study results where, increase in crop yield attributes with residual combined application of biochar and compost. Test weight and harvest index were statistically non significant in this experiment.

The critical appraisal of the Fig 1 revealed that, seed and stover yield of green gram crop. Seed and stover yield of green gram was significantly influenced by the residual effect of biochar and cow dung manure and their combined application. Residual effect of CSB at $8 \mathrm{t} \mathrm{ha}^{-1}, \mathrm{CDM}$ at $10 \mathrm{t}$ $\mathrm{ha}^{-1}$ with NPK fertilizers treatment showed significantly higher seed and stover yield (871 and $1708 \mathrm{~kg} \mathrm{ha}^{-1}$, respectively) and it was followed by CSB at $6 \mathrm{t} \mathrm{ha}^{-1}, \mathrm{CDM}$ at $10 \mathrm{t} \mathrm{ha}^{-1}$ with NPK fertilizers (789.0 and $1563 \mathrm{~kg} \mathrm{ha}^{-1}$, respectively) as compared to $\mathrm{T}_{4}\left(\mathrm{NPK}+\mathrm{CDM}\right.$ at $\left.10 \mathrm{tha}^{-1}\right)(762.0$ and $1490 \mathrm{~kg}$

Table 2: Carryover effect of biochar and cow dung manure on yield parameters of green gram.

\begin{tabular}{|c|c|c|c|c|}
\hline Treatments & $\begin{array}{l}\text { Number of pod bearing } \\
\text { auxiliary branches plant }{ }^{-1}\end{array}$ & $\begin{array}{l}\text { Pod length } \\
\qquad(\mathrm{cm})\end{array}$ & $\begin{array}{l}\text { Number of } \\
\text { pods plant }{ }^{-1}\end{array}$ & $\begin{array}{l}\text { Number of } \\
\text { seeds pod }\end{array}$ \\
\hline $\mathrm{T}_{1}:$ (absolute control) & 1.86 & 5.44 & 16.41 & 8.30 \\
\hline $\mathrm{T}_{2}: 100: 50: 50 \mathrm{NPK} \mathrm{kg} \mathrm{ha}^{-1}$ (Only RDF) & 2.45 & 7.28 & 19.08 & 10.35 \\
\hline $\mathrm{T}_{3}: \mathrm{CDM} @ 5 \mathrm{tha}^{-1}$ & 2.93 & 7.91 & 22.21 & 12.35 \\
\hline $\mathrm{T}_{4}: \mathrm{CDM} @ 10$ t ha-1 (POP) & 3.00 & 8.42 & 22.74 & 13.04 \\
\hline $\mathrm{T}_{5}: \mathrm{CSB} @ 2$ t ha-1 & 2.33 & 7.85 & 19.13 & 11.28 \\
\hline $\mathrm{T}_{6}:$ CSB @ $4 \mathrm{tha}^{-1}$ & 2.68 & 8.12 & 20.27 & 12.05 \\
\hline $\mathrm{T}_{7}: \mathrm{CSB} @ 6 \mathrm{tha}^{-1}$ & 3.18 & 8.17 & 20.82 & 12.16 \\
\hline $\mathrm{T}_{8}: \mathrm{CSB} @ 8 \mathrm{tha}^{-1}$ & 3.27 & 8.24 & 20.44 & 12.89 \\
\hline $\mathrm{T}_{9}: \mathrm{CSB} @ 2$ t ha-1 + CDM @ 5 t ha-1 & 3.13 & 8.17 & 20.21 & 11.85 \\
\hline $\mathrm{T}_{10}: \mathrm{CSB} @ 4 \mathrm{t} \mathrm{ha}{ }^{-1}+\mathrm{CDM} @ 5 \mathrm{t} \mathrm{ha}^{-1}$ & 3.33 & 8.38 & 21.68 & 12.13 \\
\hline $\mathrm{T}_{11}: \mathrm{CSB} @ 6 \mathrm{tha}^{-1}+\mathrm{CDM} @ 5 \mathrm{tha}^{-1}$ & 3.58 & 8.17 & 22.12 & 13.13 \\
\hline $\mathrm{T}_{12}:$ CSB @ 8 tha ${ }^{-1}+$ CDM @ 5 t ha-1 & 3.66 & 8.31 & 22.98 & 13.80 \\
\hline $\mathrm{T}_{13}: \mathrm{CSB} @ 2 \mathrm{tha}^{-1}+\mathrm{CDM} @ 10 \mathrm{tha}^{-1}$ & 3.93 & 8.23 & 22.76 & 12.67 \\
\hline 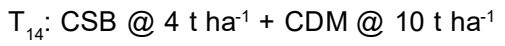 & 4.22 & 8.27 & 23.00 & 13.51 \\
\hline $\mathrm{T}_{15}:$ CSB @ $6 \mathrm{tha}^{-1}+\mathrm{CDM} @ 10 \mathrm{tha}^{-1}$ & 4.26 & 8.39 & 24.71 & 13.93 \\
\hline $\mathrm{T}_{16}: \mathrm{CSB} @ 8 \mathrm{tha}{ }^{-1}+\mathrm{CDM} @ 10 \mathrm{tha}^{-1}$ & 4.38 & 8.50 & 25.57 & 14.36 \\
\hline S.Em \pm & 0.12 & 0.59 & 0.86 & 0.88 \\
\hline C.D. $(p=0.05)$ & 0.33 & NS & 2.49 & NS \\
\hline
\end{tabular}

*Significant at P 0.05; NS- Non Significant at $P>0.05$. 


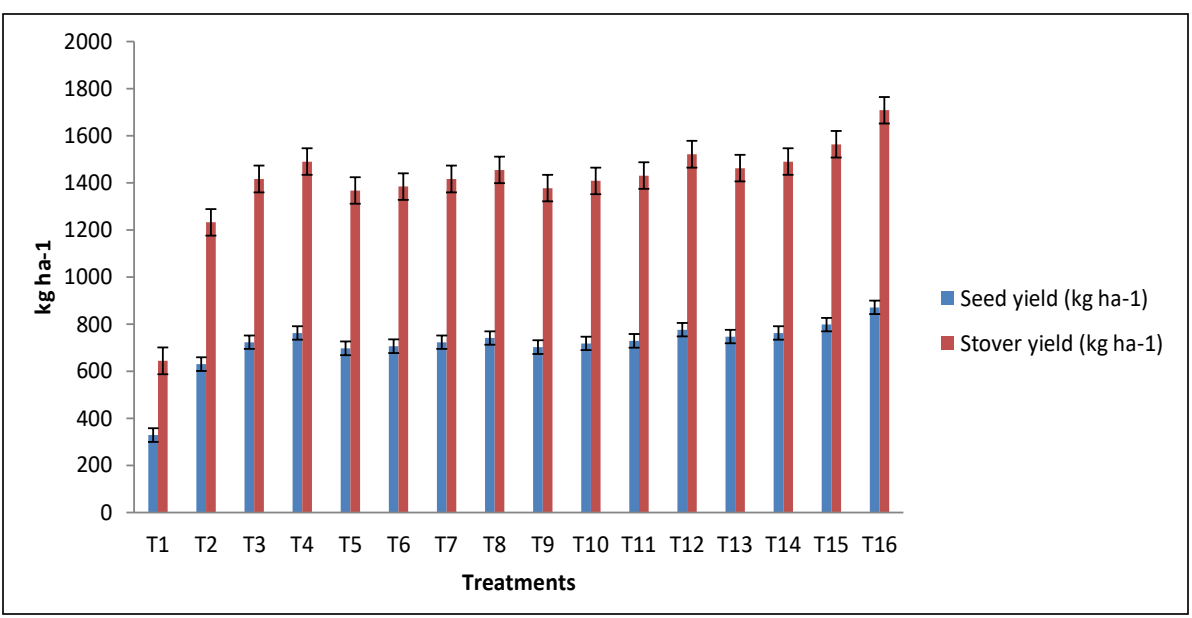

Fig 1: Carryover effect of biochar and cow dung manure on seed and stover yield of green gram.

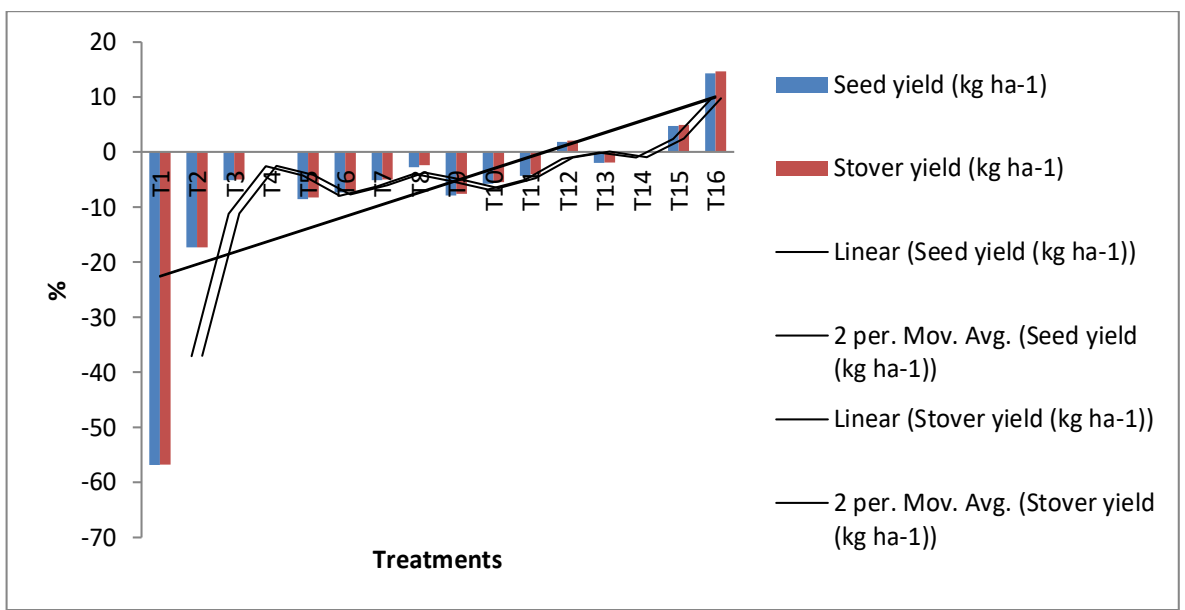

Fig 2: Per cent increase in yield due residual effect of biochar and cow dung manure on seed and stover yield of green gram.

ha $^{-1}$, respectively) and $\mathrm{T}_{2}$ (NPK alone) treatment (630.0 and $1232.0 \mathrm{~kg} \mathrm{ha}^{-1}$, respectively). The yield data indicated a significant influence of residual biochar and cow dung manure on green gram seed and stover yield. This could be mainly attributed by liming effect of biochar in acidic soil. Crops yields particularly at acid soils can be increased if biochar applied in combination with inorganic or organic fertilizers (Singh et. al., 2016). Nutrients present in the soil and in the biochar and cow dung manure, which were made available to the crop. The results given by Yooyen et al. (2015) on addition of biochar to soybean increased the number of seeds per plant. The inorganic fertilizers applied along with biochar increased the availability of nutrients to plants by performing different mechanisms, which in turn increased the yields. Along with increasing biological nitrogen fixation, biochar also significantly improved biomass production and yield of common beans. Such responses confirmed earlier results with moong bean (Rondon et al., 2007). The superiority of coconut shell biochar applied treatments over NPK fertilizers alone was due to biochar was being protected from further decomposition thereby it could undergo slow decomposition and supply longer and steady source of macro and micronutrients. However, in present study residual biochar and cow dung manure applied in combination recorded higher yield of seed and stover in the treatment $\mathrm{T}_{16}$ (residual CSB at $8 \mathrm{t} \mathrm{ha}^{-1}$ and CDM at $10 \mathrm{t} \mathrm{ha}^{-1}$ with NPK fertilizers). Which showed the percentage efficiency of 14.30 and 14.63 per cent increase in seed and stover yield of green gram over treatment $T_{4}$ (NPK alone) (Fig 2).

\section{CONCLUSION}

The carryover benefits of biochar with inorganic and organic nutrient sources showed clear increase in growth, yield and yield attributes of green gram and also associated with improvement of soil properties. The present study results are also clearly indicated that, previously applied biochar and cow dung manure showed significant residual effect on green gram productivity, especially, coconut shell biochar (CSB at $8 \mathrm{t} \mathrm{ha}^{-1}$ ) and cow dung manure (CDM at $10 \mathrm{t} \mathrm{ha}^{-1}$ ) had a strong residual effect on growth and yield of green gram. The fine grained biochar particles being locked within soil and its high $\mathrm{C}: \mathrm{N}$ ratio leads to slow mineralization thereby it could supply longer and steady source of macro and 
micronutrients and also enhance the soil moisture holding capacity for succeeding crops. Therefore, based on the results of the present study obtained it can be concluded that residual effect of previously applied biochar had a significant positive effect on succeeding crops yield in acid sandy loam soils due to its liming effect on improving soil properties.

\section{REFERENCES}

Bandara, T., Herath, I., Prasanna, K., Mihiri, S., Gamini, S., Nishanta, R., Meththika, V. and Yong, S. O. (2015). Role of woody biochar and fungal bacterial co-inoculation on enzyme activity and metal immobilization in serpentine soil. Journal of Soil Sediments. 10(7): 43-68.

Gomez, K.A. and Gomez, A.A. (1984). Statistical Procedures for Agricultural Research ( $2^{\text {nd }}$ Ed.) John Wiley and Sons, New York. pp 680.

Joseph Koireng, R., Rolling Anal, P.S., Chanu, T.M. and Priya Devi, K.H. (2018). Residual effects of organic manure and micro nutrients on growth and yield parameters of green gram (Vigna radiata)" in potato-green gram sequence. Indian Journal of Agricultural Research. (52): 333-335

Lehmann, J., Gaunt, J. and Rondon, M. (2006). Bio-char sequestration in terrestrial ecosystems: A review. Mitigation Adaptation Strategies for Global Chnange. 11: 403-427.
Mahto, S.K. and Dutta, A.K. (2018). Influence of different low-cost organic inputs on growth, yield and quality of French bean (Phaseolus vulgaris L.) cv. Swarna Priya. Indian Journal of Agricultural Research. 52: 661-665

Rambuatsaiha, T.G. and Noyingthung, K. (2017). Optimization of organic nutrient sources for green gram [Vigna radiata (L.) Welczek] under rainfed conditions. Indian Journal of Research. 51(5): 443-447.

Rondon, M.A., Lehmann, J., Ramirez, J. and Hurtado, M. (2007). Biological nitrogen fixation by common beans increases with biochar additions. Biology and Fertility of Soils. 43(6): 699-708.

Singh, A., Singh, A.P., Singh, S.K., Rai, S. and Kumar, D. (2016). Impact of addition of biochar along with PGPR on rice yield, availability of nutrients and their uptake in alluvial soil. Journal of Pure and Applied Microbiolog. 10(3): 2181-2188.

Thakuria, K. and Thakuria, C. (2018). Influence of green manuring and organic sources of nutrient application on scented rice (Oryza sativa) - linseed (Linum usitatissimum) cropping system. Indian Journal of Agricultural Research. 52: 704-707.

Warnock, D.D., Lehmann, J., Kuyper, T.W. and Rillig, M.C. (2007). Mycorrhizal responses to biochar in soil - concepts and mechanisms. Plant and Soil. 300: 9-20.

Yooyen, J., Wijitkosum, S. and Sriburi, T. (2015). Increasing yield of soybean by adding biochar. Journal of Environmental Research and Developmen. 9(4): 1066-107. 